Case Report

\title{
Pleural mass in a young male unfolding an uncommon presentation of multiple myeloma
}

\author{
Purnima Bharati ${ }^{1}$, Prajwala Gupta ${ }^{1}$, Arvind Ahuja ${ }^{1}$, Meenakshi Bhardwaj ${ }^{1}$ \\ ${ }^{I}$ Department of Pathology, PGIMER \&Dr. RML Hospital, New Delhi
}

\author{
Keywords: \\ FNAC; \\ Immunocytochemistry; \\ Multiple Myeloma; \\ Nonsecretory; \\ Pleural mass;
}

\begin{abstract}
Multiple myeloma is a malignant proliferation of the plasma cells and can be non-secretory in about 1 to 5 $\%$ cases. Pleura based mass lesions are uncommon in myeloma. Herein we report a case of non-secretory multiple myeloma presenting with a pleura based mass in a 40 year old male. Fine needle aspiration cytology with immunohistochemistry played a key role in the diagnosis of this case.
\end{abstract}

\section{Correspondence:}

Dr. Purnima Bharati MD Resident,

(C) (i)

Department of Pathology,

PGIMER \&Dr. RML Hospital, New Delhi, PIN-110001, India

ORCID ID-0000-0002-6000-5482

Email:purnimamgm@gmail.com

Received : December $15^{\text {th }} 2019$; Accepted : March $18^{\text {th }} 2020$

Citation: Pleural Mass in a young male unfolding an uncommon presentation of Multiple Myeloma. J Pathol Nep 2020;10:1681-4 DOI 10.3126/jpn.v10i1.26719

Copyright: This is an open-access article distributed under the terms of the Creative Commons Attribution 4.0 International License, which permits unrestricted use, distribution, and reproduction in any medium, provided the original author and source are credited.

\section{INTRODUCTION}

Multiple Myeloma (MM) is characterized by malignant proliferation of plasma cells derived from a single clone and an excess of monoclonal immunoglobulin production. Several organ dysfunctions occur due to the tumor, its products and the host response to it. Less than $5 \%$ cases however, can be non-secretory in nature. ${ }^{1}$ In this case report we describe an uncommon case of non-secretory multiple myeloma presenting with a pleura based mass in a 40 year old male with normal serum electrophoresis. Fine needle aspiration cytology (FNAC) along with immunohistochemistry (IHC) revealed pleural plasmacytoma which was crucial for the initial diagnosis. Further workup proved it to be a case of non-secretory $\mathrm{MM}$ with pleural plasmacytoma and multiple bony lytic lesions.

\section{CASE REPORT}

A 40 -year-old man presented to the medical emergency with exertional dyspnea, pleuritic chest pain and dry cough since 20 days. He had been on a trial antibiotic treatment, 


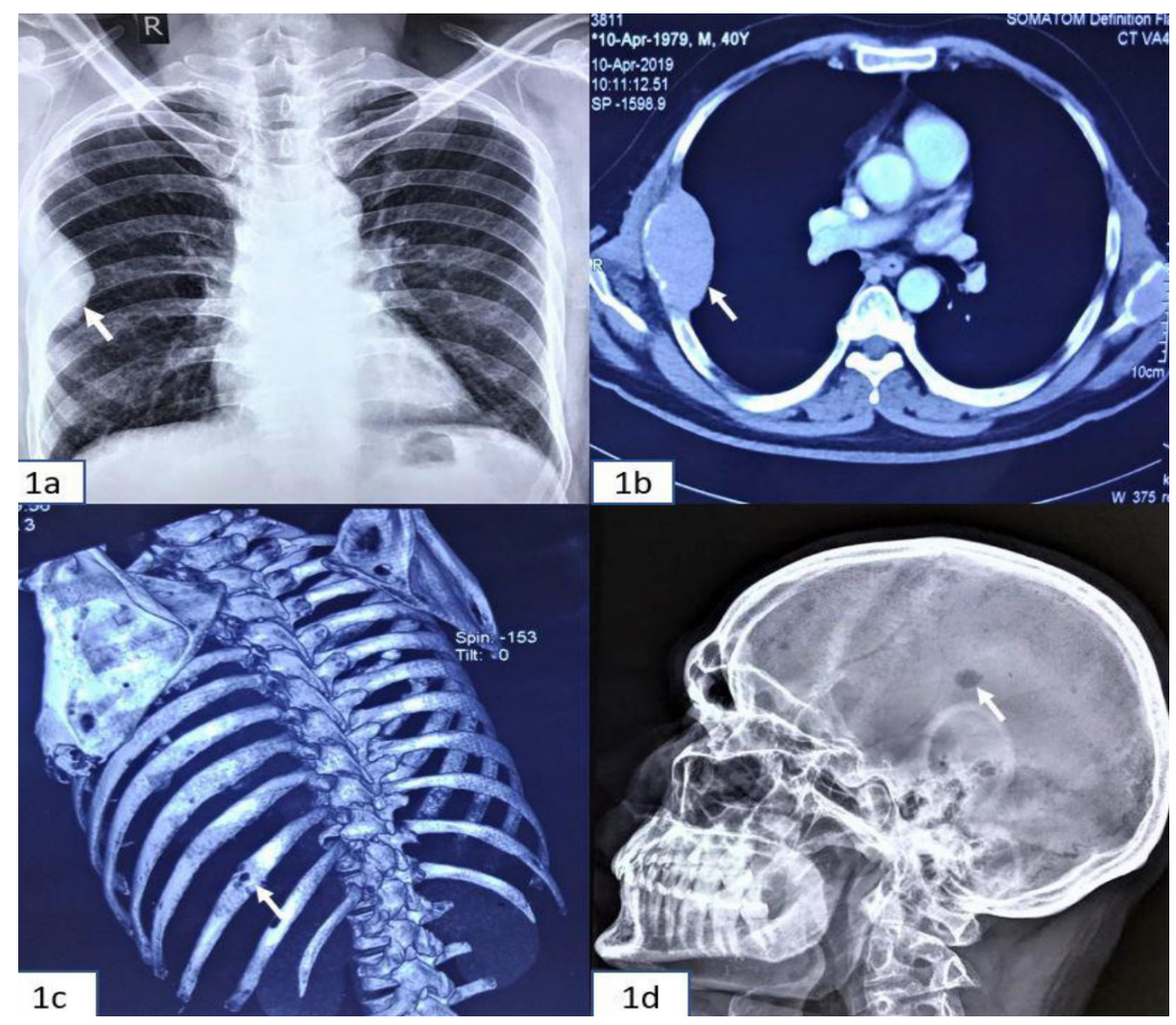

Figure 1a: Chest X-ray PA view shows focal opacity in right-sided hemithorax at the level of 4th and 5th rib(arrow) without any evidence of pleural effusion. $1 \mathrm{~b}$ : CT thorax revealed a right sided pleura based soft tissue mass measuring approx. $6.4 X 4.6 X$ $3.8 \mathrm{~cm}$ displacing the lung away from it(arrow) $1 \mathrm{c}$ : Multiple expansile lytic lesions in 5th and 10th posterior rib and inferior angle of scapula on the left side(arrow).1d-X ray skull reveals additional osteolytic punched-out lesion(arrow).

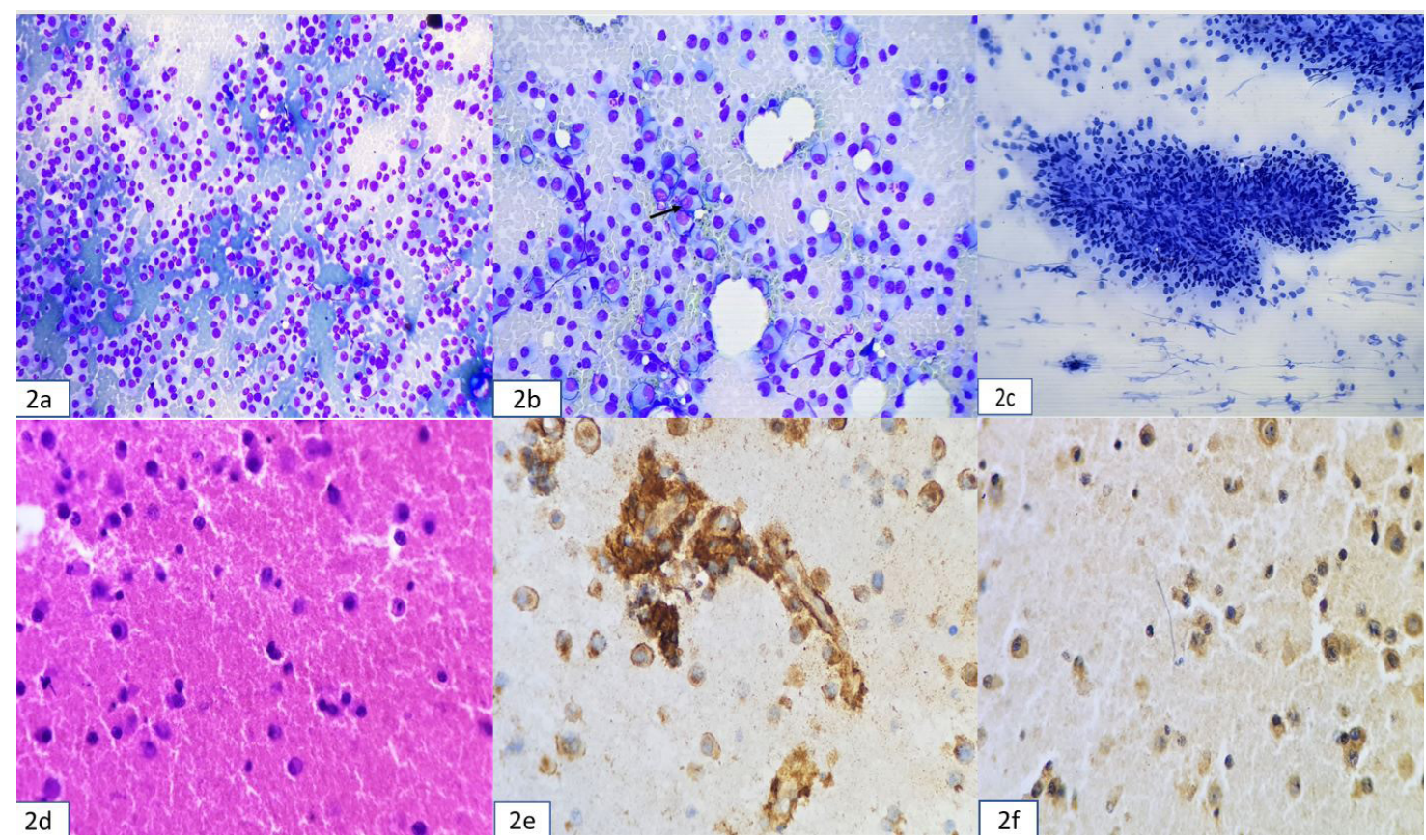

Figure 2a: Smears show numerous scattered plasma cells (Giemsa, X100) 2b: Smears shows plasma cells with immature forms having prominent nucleoli (arrow) and mature forms (Giemsa, X200) 2c: Smears show plasma cells loosely clustered around capillary channels (Papanicolou, X20) 2d: Cell block sections show many plasma cells. 2e: Section shows CD138 positivity on immunohistochemistry. 2f: IHC reveal monoclonality with kappa restriction. 
which did not alleviate his complaints. He was a chronic smoker, driver by occupation without any history of diabetes, hypertension or tuberculosis. On examination, he was afebrile with a pulse rate of $98 / \mathrm{min}$, blood pressure of 120/80 $\mathrm{mmHg}$, respiratory rate of 26 breaths/min, and oxygen saturation of $96 \%$. Systematic examination revealed mild sternal tenderness, decreased breath sounds in the left lung and winging of left scapula on overhead abduction. Chest X-ray PA view showed focal opacity in right-sided hemithorax at the level of 4th and 5th rib without any evidence of pleural effusion (fig.1a).

Computed tomography (CT) of the thorax revealed a right sided pleura based soft tissue mass measuring approx. $6.4 \mathrm{X} 4.6 \mathrm{X} 3.8 \mathrm{~cm}$ displacing pleura and lung away from it, along with multiple expansile lytic lesions in 5th and 10th posterior rib and inferior angle of scapula on the left side(fig. 1b and 1c). Sonography guided FNAC of the patient was subsequently done from the pleura based mass. Smears prepared were cellular revealing numerous mature plasma cells and immature plasma cells with prominent one to two nucleoli, few of them were binucleated (fig. 2a and 2b). Nuclear or cytoplasmic inclusions were absent. Papanicolou stained smears showed plasma cells loosely clustered around capillary channels(fig. 2c).Cell block was prepared from FNAC sample and H\&E stained sections showed sheets of plasma cells(fig. 2d). IHC revealed CD 138 positive plasma cells with kappa restriction (fig. 2e and 2f). A diagnosis of pleural plasmacytoma was made and further clinical and hematological work up was advised for MM. Extensive skeletal survey, bone marrow aspiration and serum electrophoresis was done. Serum electrophoresis was non contributary as it revealed normal results causing a diagnostic dilemma. Standard radiographs showed additional osteolytic punched-out lesion in the skull (Fig. 1d). Bone marrow aspiration revealed 34\% mature and immature plasma cells. Finally, a diagnosis of nonsecretory MM (NSMM) was made.

\section{DISCUSSION}

Multiple Myeloma is a neoplastic disorder caused by the proliferation of monoclonal plasma cells and associated with production of large amount of monoclonal immunoglobulins. However, in about 3-5\% of MM cases monoclonal band is not detected and these patients are known to have a NSMM. ${ }^{1}$ According to WHO, in these patients, there is absence of an $\mathrm{M}$ protein by serum and urine immunofixation electrophoresis. ${ }^{2}$ With advances in the detection of serum free light chain assay, it has been demonstrated that most of these previously defined NSMMs are probably oligo secretors ${ }^{3}$, producing primarily or solely serum FLC in the absence of heavy chain. Hence, the proportion of true NSMM, meaning MM that secretes no measurable monoclonal heavy or light chains at all, is closer to $1-2 \%$ of all $\mathrm{MMs}^{4,5} \mathrm{MM}$ is very infrequently seen in younger adults aged $<30$ years. The incidence increases progressively with patient age thereafter, with about $90 \%$ of cases occurring in patients aged $>50$ years. $^{2}$

Extraosseous myeloma refers to a rare manifestation of MM where there is plasma cell proliferation outside the skeletal framework and their presence has been associated with more aggressive disease. ${ }^{3}$ Extramedullary involvement in MM usually involves the nasopharynx, upper respiratory tract, or gastrointestinal tract. ${ }^{4}$ Pleuropulmonary disease is more unusual and includes pulmonary infiltrates, parenchymal masses, airway lesions, and pleural effusions. ${ }^{5,6}$ Pleural mass lesions in MM are very rare and few cases have been described previously. ${ }^{6,7}$

Abhishek K. et $\mathrm{al}^{7}$ in 2018 reviewed studies describing different thoracic presentations of multiple myeloma, including 3 patients of his own study presenting with pleural effusion, mediastinal mass, central airway obstruction, and pleural mass. There have been studies and reports describing the role of FNAC in MM and extra medullary plasmacytomas (EMP). Few authors have also dealt in detail, the role of FNAC in plasma cell neoplasms. Bangerter et $\mathrm{al}^{8}$ analyzed cytomorphology of 18 cases of EMP; they encountered abnormal plasma cells in 13 of their cases. In a study by Tani et $\mathrm{al}^{9}$ including 19 patients with EMP, soft tissue was found to be the commonest location with 9 cases and Immunocytochemistry applied on the cases demonstrated the monoclonal expression of immunoglobulin light chains in all their cases, along with CD 38 positivity. Kumar et al ${ }^{10}$ were able to accurately diagnose all their 13 cases of EMP by FNAC, using routine Romanowsky and Papanicolaou stained cytologic smears alone.

NSMM is in itself very rare and its occurrence with pleural lesion in a relatively young 40 year old male is in itself challenging. This case report highlights the importance of USG guided FNAC for providing initial diagnosis and accelerating the patient's further work up and management.

\section{Conflict of Interest: None}

\section{REFERENCES}

1. Middela S, Kanse P. Nonsecretory multiple myeloma. Indian J Orthop 2009;43:408-11. Crossref

2. McKenna R.W. Kyle RA, Kuehl W.M., Harris N.L., Coupland R.W., Fend F. Plasma cell neoplasms. In WHO classification of tumours of haematopoietic and lymphoid tissues. IARC: France; 2017. p.241258.

3. Drayson M, Tang LX, Drew R, Mead GP, Carr-Smith H, Bradwell AR. Serum free light-chain measurements for identifying and monitoring patients with nonsecretory multiple myeloma. Blood 2001;97:2900-2. Crossref 
4. Rajkumar SV. Multiple myeloma: 2016 update on diagnosis, riskstratification, and management. Am J Hematol 2016;91:719-34. Crossref

5. Chawla SS, Kumar SK, Dispenzieri A, et al. Clinical course and prognosis of non-secretory multiple myeloma. Eur J Haematol 2015;95:57-64. Crossref

6. Abdulla MC, Alungal J. Multiple myeloma presenting as pleural mass. J Assoc Chest Physicians 2015;3:33-4. Crossref

7. Abhishek K, Ejazi MA, Hashim Z, Chaudhary R, Niharika K. Multiple myeloma with different thoracic manifestations: Case series. Indian J Respir Care 2018;7:108-12. Crossref
8. Bangerter M, Hildebrand A, Waidmann O, Griesshammer M. Fine needle aspiration cytology in extramedullary plasmacytoma. Acta Cytol 2000;44:287-91. Crossref

9. Tani E, Santos GC, Svedmyr E, Skoog L. Fine needle aspiration cytology and immunocytochemistry of soft tissue extramedullary plasma cell neoplasms. Diagn Cytopathol 1999;20:120-4. Crossref

10. Kumar PV, Owji SM, Talei AR, Malekhusseini SA. Extramedullary plasmacytoma: fine needle aspiration findings. Acta Cytol 1997;41:364-8. Crossref 